\title{
THE FLAPPER AND THE FOGY: REPRESENTATIONS OF GENDER AND AGE IN THE 1920 S
}

\author{
Laura Davidow Hirshbein
}

\begin{abstract}
In the 1920s in the United States, public attention was riveted on the antics of a new, rebellious younger generation. Although popular representations focused on youth in crisis, these representations emphasized comparisons betweenyoung and old. This article explores the public discussions about youth culture in the $1920 \mathrm{~s}$ and how they helped to refine cultural categories of youth and old age. In addition, through gender-specific representations, social commentators worked out new definitions of masculinity, femininity, and the relationships between the sexes. Furthermore, the rhetorical conflict between generations of Americans helped to frame important contemporary questions about national identity.
\end{abstract}

In the 1920s in the United States, public attention was riveted on the represented antics of a new, rebellious younger generation. Within the mass culture of the burgeoning magazine and movie industries, as well as the new medium of motion pictures and expansions in advertising, one of the hottest topics of the time was youth. ${ }^{1}$ Commentators of the time wrote extensively on whether or not the younger generation was leading society toward progress or toward destruction. But while the ostensible topic of these discussions was the behavior of young people, popular representations of youth in crisis depended on a constant series of comparisons between young and old.

In this article, I explore the discussions of youth that appeared in popular magazines in the 1920s. I focus on the definitions of youth and old age that emerged from these public discussions, as well as the implications for gender standards and national identity. These popular magazine accounts certainly did not reflect the experiences of the majority of Americans, particularly those of young working-class men and women of this time period. ${ }^{2}$ Instead, the representations in popular magazines presumed a white, middle-class audience. Although the portraits of youth and old age were hardly democratic, they provide a useful way to examine changes in middle-class culture in the 1920s. Historian Lynn Hunt has pointed out that public discussions are important sources of information for historians because they not only describe opinion but also

Laura Davidow Hirshbein is a psychiatry resident at the University of Michigan Hospitals. She recently completed a Ph.D. in medical history from Johns Hopkins University, with a dissertation titled "The Transformation of Old Age: Expertise, Gender, and National Identity, 1900-1950," from which this article is derived. She is currently working on a project on popular images of depression in the twentieth century.

Journal of Family History, Vol. 26 No. 1, January 2001 112-137

2001 Sage Publications, Inc. 
help to shape reality itself. In her own work, Hunt has endeavored to "examine the ways in which linguistic practice, rather than simply reflecting social reality, could actively be an instrument of (or constitute) power. ... Words did not just reflect social and political reality; they were instruments for transforming reality."3

A number of historians have described the ways in which the language of generations was used at different times by contemporary social commentators to frame features of American society. Historian Paul Boyer has pointed out that public expressions of the relationship between young people and their families have been important means of expressing moral norms in American culture since the nineteenth century. ${ }^{4}$ In addition, Annie Kriegel has pointed out that the image of conflict between generations has been frequently used throughout the centuries, although it has had different significance in each time and place. ${ }^{5}$ In the 1920 s, commentators used the image of generational conflict to explore the implications of new and old in American society and to organize rapidly shifting social, cultural, political, and economic worlds. ${ }^{6}$ In addition, commentators used the language of generations to make sense of changes in gender ideals, as twentieth-century men articulated anxieties about loss of independence and control within the workplace, and women struggled to redefine femininity in post-suffrage amendment society. ${ }^{7}$

Not only did popular writers in the 1920s use the language of generations to articulate new roles for different generations of men and women, but also a number of commentators used images of the relationship between two generations to make sense of the nation's relationship to its past and its present. Historian Henry May has pointed out that the sometimes ambivalent relationship between younger writers from the time of the European War and the older literary elite was symbolic of modern Americans' relationship to their nineteenth-century past. ${ }^{8}$ Furthermore, Paula Fass has pointed out that the frequent discussions of youth in the 1920 s had less to do with a specific cohort of young people than a popular preoccupation with evolving national identity.

The image that teases the historical imagination is of a rebellious youth, iconoclastic, irreverent, frivolous, lost to social responsibility, and even more lost to traditional values and beliefs. While no longer tied to the past, they also rejected the present.... [This image] was, in fact, a portrait carefully constructed by contemporaries in the twenties - in the creative literature, popular journals, and volumes of social analysis by educators, judges, and poets. Contemporaries caricatured youth in order to understand and finally come to terms with the many changes which youth represented and which had suddenly overwhelmed an older order. ${ }^{9}$

The conflict between the generations had important implications for the new bureaucratic measure of American society in this time period: age. Historian Howard Chudacoff has pointed out that, by the late nineteenth and early twentieth centuries, age was increasingly used to group people. ${ }^{10}$ The rhetorical conflict between the generations helped to reinforce age groupings and develop an emerging idea of old age. ${ }^{11}$ Although Chudacoff has described age stratification across all age groups during this time period, I argue that age group recognition was uneven in the twentieth century and that consolidation of older people into their own distinct age group happened at least partly in opposition to the age grouping of young people in the 1920s.

In this article, I explore the public discussions about youth culture in the 1920s and how they helped to shape a cultural category of old age and refine a category of youth. I 
argue that, through gender- and age-specific (as well as class-specific) representations within American mass culture in the 1920s, social commentators worked out new definitions of youth and old age, as well as masculinity, femininity, and the relationships between the sexes. Furthermore, the rhetorical conflict between generations of Americans helped to frame important contemporary questions about national identity. The language of generational conflict became more and more pervasive during the $1920 \mathrm{~s}$ such that, by the 1930s and 1940s, the perceived differences between young and old were used more and more to justify professional actions and economic adjustments. ${ }^{12}$ Furthermore, the differences between categories of generation and gender helped to reinforce gender-specific age discussions for many subsequent decades. ${ }^{13}$

\section{YOUTH AND OLD AGE}

In 1921 and 1922, the editors of the Literary Digest, one of the most widely read periodicals in America at the time, addressed the pressing contemporary issue of the nation's troubled youth. Asking "Is the Younger Generation in Peril?" the editors polled their colleagues in the press, college professors and presidents, philosophers, novelists, and religious leaders for opinions on what appeared to be radically new attitudes and behavior in young people. The Literary Digest coverage captured many of the issues that were constantly being discussed in contemporary periodicals, books, fiction, and films about young people's new freedoms in speech, behavior, and dress. ${ }^{14}$

The articles in the Literary Digest particularly focused on representations of four typical figures: the older woman, the younger woman (the flapper), the young man, and the older man (the fogy). These stock figures were frequently juxtaposed with each other within the popular literature of the time. Portraits of youth and age emerged from the comparisons and contrasts between these stock figures. Through their praise, as well as their criticism, of the younger generation of the 1920s, social commentators and cultural critics compared the attitudes and behavior of youth with those of the older generation. As one journalist explained, the problem with the younger generation was really "a conflict between the conservative point of view of a past generation and the eager, liberal outlook of a modern age." 15 Thus, when contemporary critics exclaimed over a crisis of youth, they articulated a clash between a new generation and its predecessor.

Journalists and popular writers in the 1920s used readily recognizable stereotypes to portray the characteristics of both generations within popular literature. The younger generation was portrayed through representative middle-class, energetic figures who were born in the twentieth century, participated in the European War, and eagerly consumed the latest technology. Representations of young men emphasized their quickness of action and their expedient abandonment of older social niceties, while representations of young women highlighted their short hair and shorter skirts and sometimes their new right to vote. The older generation was portrayed as a group of parents or grandparents who were born in the nineteenth century, remained committed to Victorian morality, and were nostalgic about the past. Older men were associated with a more conservative outlook on politics and dress, while older women were connected to older ideas about morals and manners. ${ }^{16}$ Narrators within popular magazines generally adopted a position with one of these stock figures and then invited readers to position themselves on either side of the generational divide. ${ }^{17}$ 
These generational representations bore only a small resemblance to real social cohorts. As Fass has pointed out, portraits of youth in 1920s popular literature centered on the relatively small population of young men and women in the colleges and universities, as well as those who went to France during the war, and did not correspond to the social world of most young people of the time. ${ }^{18}$ Furthermore, the representations of the older generation did not map out onto a specific demographically identifiable group at all. One writer, who identified himself as part of the older generation, pointed out that the common association of his generation with the Civil War was not necessarily accurate. The younger generation apparently believed of the older

that they are the Victorians, they are the Howells and his contemporaries, they are the men and women who created the family magazine, invented morality, revived Puritanism, and tried to impose evolution on a society that preferred devolution by international combat. But these men are all dead, or have ceased writing. They are not our older generation. ${ }^{19}$

These representations of the older and younger generations served a rhetorical purpose and were useful ways of expressing social change, as well as conflict over contemporary issues.

In 1920, the Atlantic Monthly ran a series of four articles on the topic of the younger generation, one each from the point of view of an older man, an older woman, a young man, and a young woman. Each narrator represented himself or herself as one of the figures of a family drama. The conflicting points of view of these four narrators, the ways each represented himself or herself, and the ways in which the narrator represented the other figures make this quartet of writings a good illustration of the characters in the generational conflict of the time. Each of these figures presented a characteristic point of view on tradition and change, old and new, and the contest between young and old in America.

The first in the series was an article by an older man, writing under the pseudonym "Mr. Grundy" (an appellation presumably referring to the literary stock figure of Mrs. Grundy, a symbol of inflexible and outdated morality). Claiming authority because of his years of experience, as well as his sex, Mr. Grundy reported that society was on the brink of collapse because people were not behaving according to their traditional roles. Mr. Grundy complained that older women were overindulgent and that members of the younger generation were behaving in a reckless and irresponsible manner. In his particular focus on the wild antics of young women, Mr. Grundy asserted that older men were still the governing figures in society. He identified himself with all those older men who shared "the trusty sledgehammer of Parental Authority" and argued that "it is for us middle-aged fathers and uncles to do our share toward restoring social law and order-peaceably if we can, forcibly if we must." ${ }^{, 20}$ As Mr. Grundy illustrated, the representation of the older man in 1920s popular literature constantly emphasized the power of his experience and the tradition of male authority. ${ }^{21}$

Like Mr. Grundy, author and Bryn Mawr faculty member Katharine Fullerton Gerould blamed the younger generation for society's ills. While Mr. Grundy emphasized older men's power to act, Gerould represented the importance of protecting the traditional and moral fabric of society. She blamed the decline of religion for social disorder, particularly the weakening of religious impulses over time. 
Humanity will go the primrose path unless forbidden by some power in which it believes. ... The parents of this younger generation that is shocking us kept ... their morality when they threw over their religion. But they cannot pass on that morality, except in a weakened form, when the religion is gone. ${ }^{22}$

Gerould emphasized the moral authority of older women in promulgating the value of tradition. ${ }^{23}$

While Mr. Grundy and Gerould blamed the younger generation for disrupting the traditional social order, the spokesmen for the younger generation criticized the old-fashioned notions and inflexibility of the older generation. John F. Carter Jr., who identified himself as one of "these wild young people," spoke for the group of younger men recently returned from combat in the European War. Like most of his contemporaries, Carter spoke of his generation of men in terms of their war experience, even though most young men in the United States did not fight during the European War. ${ }^{24}$ Carter claimed for himself and for his generation not only veteran status but also the moral authority of the first truly modern generation in which manners and morals took second place to new technologies and reordered imperatives after the war. Carter took issue with both the "maiden aunt" sensibilities of Gerould and the "oldster" mentality of Mr. Grundy and claimed wisdom for the younger generation because of their intense experiences with war. In Carter's representation, the older generation was tired and foolish and still too powerful in society.

We have seen the inherent beastliness of the human race revealed in an infernal apocalypse. It is the older generation who forced us to see all this.... And now, through the soft-headed folly of these painfully shocked Grundys, we have that devastating wisdom which is safe only for the burned-out embers of grizzled, cautious old men. ${ }^{25}$

For Carter, the virtues of experience and wisdom belonged to the younger generation while there was nothing left for the older generation but to bow out gracefully.

Finally, the most notorious figure of the time, the modern young woman (or flapper), contributed her opinion "to round out the quartette." "A Last Year's Debutante" likened the experiences of the younger generation to the challenges of the new world:

Motors, movies, jazz-music, freedom of action, liberty of thought, the rights of individuals - all these facts and theories surround us, threaten us, excite us, and tempt us. We are experimenting with vital things, and we are bound to make mistakes; only, dear Mr. Grundy, don't let your contemporaries judge us without realizing the seething, bubbling, changing, electrical world into which we have been flung - as unprepared as was America herself for the struggle from which she emerged triumphant, though very faulty and somewhat smirched. ${ }^{26}$

The young woman's representation of the younger generation identified it with the nation itself. In her formulation, the younger generation was doing the important business of gaining experience. There was no value in the knowledge gained by the older generation because it was of a world gone by.

The representations of the older and younger generations revealed very different ideas about old age. The two spokesmen for the older generation emphasized older men's traditional power and older women's moral authority. They also assumed that members of the older generation would have superior wisdom to evaluate the new 
world. For the members of the younger generation, however, the only valuable experience was that gained in the modern world. Furthermore, because younger people were immersed in the massive changes of the new century, the experiences of older people were useless and sometimes even harmful.

\section{GENDER AND AGE}

In the 1920s, mass culture discussions about middle-class youth involved not only a comparison between young and old but also a comparison between young and old men and women. By that time in the United States, there had been dramatic changes in the social and cultural relationship between men and women. In the nineteenth century, as historians of both men and women have pointed out, homosocial community organizations were essential to American society. ${ }^{27}$ In addition, the cultural ideology that separated male and female was one of the most powerful defining characteristics of nineteenth-century American culture. ${ }^{28}$ In the twentieth century, however, men and women had more and more public interactions. The public discussions around generational conflicts revealed other conflicts as different generations of men and women tried to make sense of new gender relationships. ${ }^{29}$

Through popular discussions of generational conflict, gender and age categories complicated each other. Older women's traditional power of organizing for women's causes was held up next to young women's new political and educational freedoms, while older men's traditional social power was juxtaposed to younger men's energy and quickness. Ultimately, social commentators articulated a complicated system of oppositions in which definitions of masculinity and femininity depended on age. In the process, the power gained by an older generation of women through their social action in the nineteenth century was debunked in favor of a reification of women's roles as wives and mothers. In addition, older and younger men became increasingly separated as masculinity became defined in terms of energy, quickness, efficiency, and physical prowess, qualities that did not match with older men's strengths of wisdom and maturity.

As Gerould's article in the Atlantic Monthly series illustrated, the figure of the older woman based her authority on her role as arbiter of morals and manners. As historian and literary critic Ann Douglas has described, however, the figure of the older woman was under attack in American culture in the early twentieth century. Although some commentators in the 1920s attempted to remind readers of women's nineteenth-century moral accomplishments, Douglas has pointed out that the matriarch was frequently targeted as an obstacle to modernism. ${ }^{30}$ Commentators used the figure of the older woman as moral authority to critique young people, but many also attempted to minimize women's authority through emphasizing the triviality of women's traditional moral standards, as well as through unfavorably comparing the matriarch to the younger generation of women. ${ }^{31}$

As Douglas has observed, representations of older women's authority within the popular literature seldom supported older women's claim to moral superiority. Instead, older women's inflexible moralism was criticized for its focus on trivial matters amid much larger social issues. Some writers showed the pettiness of older women's concerns through representing generational conflict in terms of manners. In these representations, older women's assessment of the great crisis of the younger generation tended toward the ridiculous. One New York hostess revealed her outrage about the 
ways in which the younger generation offended her social sensibilities, and she equated bad social behavior with the downfall of society.

To be specific, these are some of the ways in which the younger men and women of smart society to-day offend in propriety: They take for granted the favors shown them by older people, seldom acknowledging in the slightest degree their social debt. For seasons past young guests have been known to leave the private dinner and supper dances without making their adieus to the lady who gave the party. And often the late arrivals have dashed in, the girls after leaving their wraps and snatching a puff of their cigarets [sic], have dived into the dancing without even the customary formality of greeting the hostess.

This writer argued that manners were inextricably tied to morals, and thus the behavior of the younger generation was illustrative of significant national difficulty. "The world is in a chaotic reconstructive period, and it is disturbing to feel that the foundations of the social structure are trembling. ${ }^{\prime 32}$ Though this author was earnest in her suggestion that party manners were a significant component of the fabric of society, most representations of older women tended to mock older women's insistence that social niceties and little conventions held America together. Since women's concerns were represented as trivial, women's older role as guardian of morality seemed to be in question.

One of the most noticeable critiques of older women came through contemporary writers' comparisons between younger and older generations of women. Historian Peter Filene has pointed out that generational conflict between women was important to the decline of feminism in the 1920s, as younger women disagreed with their elders over politics, marriage, and sexuality. ${ }^{33}$ Within the older model of female behavior, women of all ages were expected to try to better society through the special interests of women. Many older women were disturbed by young women's refusal to identify with older moral and political agendas. Feminist reformer (and member of the older generation) Charlotte Perkins Gilman agreed that the freedoms of the younger generation could be exhilarating, but "gay and proud and impudent, they have escaped from authority and duty and decorum, and, like Humpty-dumpty, have had a great fall." Gilman further lamented that young women were wasting their freedom by focusing their energies on a frivolous pursuit of fun rather than trying to better their sex and their race. She implored all women to continue to seriously consider the weighty issues with which her generation had struggled, and she insisted that women's new freedoms would be for naught if young women only pursued their own pleasure. ${ }^{34}$

While some older feminists such as Gilman criticized younger women for their moral laxity, many commentators favorably represented younger women's free behavior in contrast to the restrictions of the older generation. ${ }^{35}$ Even some older women participated in describing a new kind of femininity, one that had eliminated the problems experienced by the older generation of women. These older women writers argued that the world of their youth was repressive and that young women represented a better future for all women. As one older woman commented, younger women required guidance rather than blame:

In the old days there was great likelihood that girls might remain ignorant of most of the problems connected with social vice and irregular sexual relations. Their world was small and fixed, and there was no possibility for them to widen its bound- 
aries. ... But the modern girl knows enough to be aware that there are problems and questionings, and yet she is not given that frank, clear instruction which would enable her to understand that there is a real and substantial reason for many of the "thou shalt nots' which seem to her to be mere harassments. ${ }^{36}$

In this way, older women presented younger women's freedoms, while excessive, as a vast improvement on the conditions they endured when they were young.

In the comparisons between young women and old women, older women were represented as part of an older moral order, one that did not necessarily have any relevance in the modern world. Younger women were represented as more free and energetic but without the moral authority exercised by an older generation. While some women emphasized the bonds between women of all generations, particularly in opposition to men, younger women tended to ally themselves with the younger generation of men in opposition to the older generation of both sexes.

Through popular representations of the alliance between young women and men, the moral standards of older women appeared even more outdated and remote. A younger spokesman replied to a critique of his generation's manners by arguing that the older generation was trying to escape broader issues by focusing on the younger generation's behavior: "It might seem that the older generation seeks to divert censure from itself for the evils of war and the pangs of peace by casting blame on youth." Furthermore, this young man argued that the younger generation was justified in its behavior:

We have seen hideous peculation, greed, anger, hatred, malice, and all uncharitableness, unmasked and rampant and unashamed. We have been forced to live in an atmosphere of 'to-morrow we die,' and so, naturally, we drank and were merry. We have seen the rottenness and shortcomings of all governments, even the best and most stable. We have seen entire social systems overthrown, and our own called in question. ${ }^{37}$

The figures of younger men and women, who claimed that they were only reacting to the serious upheaval after the European War, contrasted with the older women's concerns about sustaining a moral order based on rules of etiquette and feminine influence.

Another way in which younger women and men were represented as allied against older women was in the arena of sex. While some older women commentators agreed that the discussions around sex in their own generation had been too limited, the younger generation went much farther by embracing the work of Sigmund Freud and the sexual freedom they read into his theories. As Leslie Fishbein has argued,

Psychoanalysis had proved useful to the postwar generation as a means both of scoffing at Victorianism and searching for new bases of social behavior. However, Freudian doctrine was commonly misinterpreted to justify sexual license, to provide a scientific justification for sexual expression. ${ }^{38}$

Some commentators at the time argued that young people had an obligation to develop in the area of sex: "The two most important aims in the education of boys and girls should be the gradual emancipation from parental control and the achievement of a healthy heterosexuality. ${ }^{39}$ Younger women and men embraced the new freedom of 
expression in sexuality sanctioned by their view of Freud, while the older generation lamented the past when morality was more strictly defined.

The generations of women illustrated two different versions of femininity: older women were reminders of a time when women socialized with one another and were active in causes for women, while younger women emphasized their new freedoms and new possible relationships with young men. But at the same time that younger women were insisting that all young people had more in common with each other than with the older people of the same sex, there were some commentators who articulated a timeless definition of womanhood in opposition to manhood. Much of this discussion was generated by male members of the older generation, and it located the problems of society in the ways in which younger women rebelled against traditional male authority.

From the perspective of the older generation, one of the major problems with the younger generation was that young women had increased their demands for social and political participation. In the process of describing this problem, commentators referred to essential qualities of womanhood, qualities that could cause problems if not channeled correctly. As an editor of the Nation explained,

The postponement of marriage has reduced the number of children born, and has therefore released for other functions a vast amount of human energy once devoted by very young women to gestation and lactation. Anyone who has had occasion to observe a group of girls in the schools and colleges of this generation knows how tremendous is the store of surplus energy for which there is no biological outlet and which too often fails to be sublimated as it might well into other forms of service. ${ }^{40}$

Many narratives about younger women emphasized the paramount importance of their reproductive functions, and commentators frequently worried that this reproductive energy was being lost. Anxieties about the younger generation of women were linked to disputes about birth control and fears of race suicide among white, middle-class observers. $^{41}$

While some writers worried about the changing habits of women in the twentieth century, others dealt with contemporary anxieties about women by asserting that women had always been essentially the same. Psychologist (and older man) G. Stanley Hall confidently predicted that, while modern women had temporarily abandoned the characteristics of their sex, they would soon return to behavior more compatible with their biological destiny.

In all the long struggle for emancipation, sometimes called the war of sex against sex, woman has, and perhaps necessarily, laid aside for the time some of her most distinctive traits, and competed with man along his own lines, and perhaps grown thereby a trifle masculine. But true progress demands that sex distinctions be pushed to the uttermost, that women become more feminine and men more virile. This need modern feminism has failed to recognize; but it is just this which flapperdom is now asserting. These girls not only accept, but glory in, their sex as such, and are giving free course to its native impulses. Underneath the mannish ways which [the flapper] sometimes affects, she really vaunts her femininity, and her exuberance gives it a new charm. ${ }^{42}$

While historian Carroll Smith-Rosenberg has pointed out that the New Woman of the 1920s represented a challenge to traditional notions of femininity, contemporary 
observers such as Hall minimized the flapper's freedoms by reiterating the binary distinction between women and men. ${ }^{43}$ Hall's comment illustrated one strand of popular representation of women's new freedoms and actions. He and other writers emphasized the ultimate differences between men and women and the essential qualities of womanhood.

While younger women's educational and work opportunities in the 1920s had given them freedoms hardly imaginable by their mothers and grandmothers, many observers framed all of women's new activities in terms of the timeless roles of wife and mother.

When I read . . . of the manifold progress which the modern girl has made over her mid-Victorian and late Victorian predecessors; when I hear, as I constantly do hear, of her efficiency as a business-girl, of her prowess as an athlete, of her achievements in the realism of art, science and literature, I cannot help asking myself the question. . . . Can the modern girl love? ${ }^{44}$

Repeatedly asserting that women's role had always been only to love, to marry, and to make a proper home for her husband and children, many commentators minimized women's freedoms and instead reiterated an essential opposition between women and men.

Representations of women tended to emphasize women in relationships with men as wives, mothers, and daughters. One older man asserted that he would not have trouble with his daughters as long as they remembered that relationship: "[I told my six daughters] so long as you remain the sensible, good representative, unspoiled daughters of an understanding American daddy, who loves, understands, and adores you, you may wear any costume that you fancy." ${ }^{45}$ Another claimed that, regardless of external appearances, girls had always been the same because their relationships continued to be central to their identities:

For a girl is what the world has needed and what life has created, working slowly from far-off times till now. Cherisher of wounded, wearied men, nourisher and guardian of helpless children from of old, she has become the little sister of all mankind, supremely interested in people. ... No matter how selfish or how artistic or how athletic she may be, she measures her happiness, not by things achieved or by obstacles and enemies overcome, but by persons pleased. ${ }^{46}$

Commentators were particularly anxious to show that younger women wanted to please their families and friends and did not in fact want to turn the social order on its head.

Although some commentators were confident of the eternal qualities of all women, others worried that new freedoms were allowing young women to betray the trust of their sex. Some blamed the vote for young women's excessive behavior: "Political and economic liberty ... has come to women, who, retaining their sex instincts and yet not knowing how to use their freedom, are apt to claim the virtues and ape the vices of men." ${ }^{, 7}$ Other commentators believed that young women would not behave irresponsibly if they were not encouraged by young men, allowed to frolic by lax mothers, or improperly disciplined by fathers. A spokesperson for the YWCA in New Jersey commented that beauty pageants, turned "splendid examples of innocent and pure womanhood" and "filled [their heads] with vicious ideas." ${ }^{48}$ Some male writers lamented the 
loss of traditional female characteristics and called on old and young women alike to return to the traditions of the older generation.

Other commentators emphasized the failings of both generations of women: modern womanhood was in jeopardy because young women misbehaved and older women failed to discipline them. One principal of a private Massachusetts high school told a story of a young man who conveyed his dismay at women.

He related how he and a friend had been asked by the matron at a fashionable dance to take home a young girl who was too drunk even to help herself; how they had placed her in a taxi and had deposited her limp form in the hallway of her sumptuous home, where the mother, with no sign of distress, had graciously thanked them for what in her eyes appeared be an ordinary attention. He told me more, much more; but it were best left unsaid. And then, as he ended with the frank admission of his inability to stand against the tide, he turned to me and said in a tone of very real distress, "What can a fellow do?",49

Writers such as this older man emphasized connections between generations of men in opposition to the problematic behavior of all women.

Some men were particularly worried about how changing ideas of femininity would affect them. One older man framed his anxieties about women's behavior in terms of women's moral influence. He pleaded for a return to "old standards of morality" because

there is nothing to tell a boy that he should believe that womankind as a whole is pure and modest and high-minded and far better than he is, and demands of him, for his own sake and for hers, that he shall live clean and meet her on an equal plane. ${ }^{50}$

Some writers turned to older representations of women that emphasized women's place as moral authorities, while others rejected women's authority both old and new in favor of male prerogative. Several editors who were polled by the Literary Digest about the problem of the younger generation praised the Digest for its "attempt to make this world safe for masculinity." ${ }^{51}$ While the editors of the Literary Digest somewhat ironically suggested that controlling younger women's outfits and behavior might save the world for men, a number of male writers expressed a hostility, almost to the point of violence, about the need to control young women. ${ }^{52}$ As Mr. Grundy reported to the Atlantic Monthly, "If woman resorts to barbaric methods of conquering young men, old men must retaliate by adopting uncivilized warfare to subjugate woman. ${ }^{, 53}$ For many men of this time period, young women's freedoms were simply incompatible with the older social order.

While some writers attempted to reassert the binary opposition between men and women, there was an increasingly important split between generations of middle-class men. In particular, representations of men showed a rift between types of male authority. In the areas of education and politics, the figure of an older man was used to represent tradition, authority based on experience, and the wisdom of long life. In contrast, the figure of a younger man represented modernity, the rapid accumulation of experiences in modern life, and the superiority of energy over wisdom. Through the conflict between the representations of older men and younger men, traditional authority was called into question. 
For example, older men identified themselves and were associated with an older system of education, one that relied on ancient texts and frequent reference to European traditions. Older educators lamented the lack of education of the younger generation, as well as the general lack of interest in appropriate learning material among young people. The writer, philosopher, and Harvard professor George Santayana remarked that young people had difficulty with the traditional college curriculum because of their new point of view.

I was ... not at all surprised that the life of the ancients, although alone truly human and addressed to a possible happiness, should not appeal to young America. It is too remote, too simple; it presupposes the absence of this vast modern mechanical momentum, this rushing tide of instrumentalities on which young America is borne along so merrily. ${ }^{54}$

While older educators insisted that the classics were timeless and useful to all, the older traditions were often juxtaposed with younger people's assertions that the immediacy of American experience was superior to the imported wisdom of the ancients.

Younger writers insisted that education needed to be fresh and vigorous, alive and relevant. They were scathing in their critique of the educational habits of previous generations.

The old way of teaching produced indoctrinated young ostriches. One scribbled down notebooks full of dead information delivered once and for all by desiccated lecturers and then passed it back again in examinations, solemnly as though it were a corpse. ... To learn through direct contact with the problems of life, not our own exclusively but other people's too,- - that is becoming more articulately and widely our aim. ${ }^{55}$

In this representation of the younger generation, the wisdom of the older generation was no longer necessary, as young men emphasized their closer relationship to experiences most relevant to their lives.

Politics was another area of authority that showed a contrast between older men's wisdom and younger men's energies. While they conceded that the younger generation was enthusiastic, older commentators argued that young men were not responsible. Older men also claimed to have a greater understanding of the world as well as greater wisdom and clarity. As one older editor pointed out,

The fact is that the sound thinking of the world has never been the product of youth, aside from an occasional and luminous genius. Old men for council, and young men for war. It would appear self-evident that our youthful theorists, scarcely able as yet to cope with the business of earning their way through the world, are not to be trusted with the rather particular matter of moral revolution. ${ }^{56}$

In the worldview proposed through a sympathetic representation of older men, men needed to prove their capabilities in everyday life before they could begin to address the magnitude of political problems.

Another divisive issue for American men was the European War. Commentators divided generations of men based on their role in the war. "On the one side are the 'old men,' who stand for the conditions which bred the war-for the war, in short; on the 
other the young, who stand for a new world." ${ }^{57}$ Young men blamed older men for beginning the war and criticized their inability to look to the future and preserve the world for the next generation. Young men also insisted that their own participation in the European War was enough experience to give them equal power as older, and theoretically wiser, men.

They tell us that we are too young and uninformed to handle momentous questions, but when the country gets into trouble like war, the whole job is shoved on our shoulders. If we are wise enough to fight, we are wise enough to prevent wars. ${ }^{58}$

While representations of older men emphasized the wisdom and experience of age, younger writers tried to claim that modern experiences were more intense than those of the older generation and therefore that younger people were better experts on modern problems than their elders were.

Not only did younger men claim that modern experience was superior to the wisdom accumulated by their elders, but they also claimed that advanced age produced infirmity that disqualified older men. ${ }^{59}$ One author argued that older men's inability to fight in the war was not only an indication of their age but also a cause of further advance into old age: "They have become older, not because they have lived through a larger experience, like the younger men, but because they have become further removed from that which makes men young." ${ }^{\circ 0}$ In addition, younger writers questioned whether old men were really wiser: "The tendency in political life-at least in an industrial democracy - is to confuse seniority with superiority and old age with ability." ${ }^{61}$ Younger men emphasized the physical and emotional failings in old age and suggested that there was no necessary correlation between age and wisdom.

While many commentators, young and old, suggested that middle-class masculinity was different for different age groups, some older men emphasized male bonds that united the generations. While younger men may have participated in the European War, older men illustrated that all men spiritually participated in war.

I am certain that a very great majority of the young soldiers known to me give us others the credit at least that we believed we were sorry not to be with them, and were ashamed to be in safety while they faced what they had to face. ${ }^{62}$

Indeed, some older writers called on military metaphors to remind young men that all men were in the fight together, and even as young men went off to battle for a modern new world, the older veterans of life's struggles would applaud.

Remember all the time that we're right behind, bragging about you, calling to the tired veterans of the army to stand up and cheer for you. You're going to plant your flag on that peak yonder that we never dared attempt. ${ }^{63}$

While representations of young men during this time period were often linked to heroic action during the European War, some older commentators were anxious to show that the ability to make war was not the defining element of modern masculinity. Instead, older men showed men's common sympathies as ways of linking the male generations. ${ }^{64}$ 
In the hierarchies of power elaborated through discussions of generational conflict in the 1920s, the ultimate victors were young men who combined the energy and quickness of the modern generation with the new qualities of masculinity. Younger women's efforts to ally with young men were hampered by commentators' reminders of the eternal qualities of womanhood, qualities that would be best used if women stayed home with their children. Older women's moral authority declined throughout the early part of the twentieth century, and as Douglas has pointed out, the cultural authority of the matriarch was eventually debunked as an obstacle to modern progress. Finally, older men's distinctive kind of power was increasingly distanced from the evolving notions of masculinity through the 1930s and 1940s. The most enduring legacy of the public discussion of the generations in conflict in the 1920s was the difference between young and old men, in opposition to most women.

\section{CONFLICT, MEMORY, AND NATIONAL IDENTITY}

The public discussion of the problematic younger generation revealed different images of old age from the perspective of the older and younger generations, as well as the emerging distinction between young and old men. Furthermore, this discussion revealed national uncertainty about conflict, the changing role of memory in American culture, and changes in national identity in the aftermath of the European War. During the 1920s, when the problems of generational relationships appeared to be everywhere, commentators could accommodate the language of generational opposition to describe racial strife, changes in technology, and Americans' relationship to the past.

While some commentators insisted that the conflict between the generations was the most pressing issue for Americans in the early twentieth century, there were obviously other, quite important changes to American society going on at the time. For example, as Douglas has pointed out, one of the perceived threats to white culture during this time period was the rising prominence of the New Negro. ${ }^{65}$ Some writers within the popular literature of this time period displaced anxieties about race and social change onto a conflict between different age groups. For example, one writer argued that the division between the generations was as serious and as insoluble as race relations:

The old and the young are as far apart in point of view, code, and standard, as if they belonged to different races. . . . Let us frankly - if regretfully - accept as a premise that the two generations are natural enemies, suspicious of each other, critical, distrustful, unsympathetic, and hostile. ${ }^{66}$

This doubling of race problems with generational conflict could be less threatening than confronting real racial antagonism because no matter the extent of conflict between members of a small (presumably white, middle-class) family, they were still a family. On the other hand, though, the language of the threat of race relations could express contemporary anxieties about the collapse of family life, a recurring fear for American social commentators throughout the twentieth century. ${ }^{67}$ If the hope for the future was the unity of the white family, conflict between the generations was extraordinarily disruptive. ${ }^{68}$

Some social commentators explained and attempted to contain threatening social change within the language of generational conflict. For example, dramatic changes 
such as the introduction of new technologies could be understood within the framework of generations of a family. As contemporary commentators frequently pointed out, the younger generation was the first to grow up with many modern new conveniences such as the automobile, and this set their experiences apart from that of the older generation. Journalists and other writers contrasted pastoral simplicity and mechanical innovation through examples of how differently the older and younger generations had lived their lives.

In other days the boy paid court to his 'girl' on an ivied porch or in a cosy parlor, under the watchful eyes of a mother or the stricter vigil of a maiden aunt. If he took the girl 'buggy-riding,' it was necessary for no great distance, and the return was usually long before the stars had begun to fade. The courting couple were never far from some sort of chaperonage. Impressionable and impulsive, they lived within the exterior restraints of a community observation and judgment, in face of direct family and community control, which were a considerable safeguard. But nowadays the gay young gallant steps on the gas, and the pair are soon beyond any sort of parental or other surveillance. $^{69}$

Commentators often wrote glowingly of the possibilities available to the younger generation from new technologies, but many also expressed concern that those technologies would irrevocably change human behavior. While most writers within the popular press appreciated the new technologies, they wrote about the old ways of doing things in rosy, nostalgic terms.

Historians have pointed out that American culture in the late nineteenth and early twentieth centuries contained both enthusiasm for the modern and nostalgia for the past. T. J. Jackson Lears has observed the extent to which nostalgia for the world gone by was an important element in early-twentieth-century life. ${ }^{70}$ Michael Kamman has argued that modernism could be countered through the systematic recollections of the past. He has pointed out that during the 1920s Americans made literary canons of great authors, while tourism in this country boomed with the creation of numerous historical sites. ${ }^{71}$ Within the popular literature of the 1920 s, young people who were born in the twentieth century represented modern efficient methods, while older people brought up in the nineteenth century stood for tradition and history. Just as most Americans were ambivalent about the relationship between progress and tradition, so most commentators revealed some ambivalence about the relationship between modern youth and traditional age.

Before the European War, older people (particularly literary elites) symbolized the stately tradition of the nineteenth century. Historian Henry May has described the occasion of author William Dean Howells's seventy-fifth birthday in 1912, as "really a testimonial to the unity, excellence, and continuity of American nineteenth-century civilization." ${ }^{.72}$ In addition, memory of the past, as shared by older figures in society, could also be important to help interpret present events. Historian David Kennedy has pointed out that the memories of Civil War veterans played a central role in shaping the twentieth-century imagination of war. Not only were men such as Theodore Roosevelt and Woodrow Wilson old enough to remember the war, but also, Kennedy has shown that the older men's memories of war at the time of the European War helped to shape the connections between masculinity and war in terms of heroic contests and a chivalric tradition. "An older generation ... preached that combat offered adventure-filled 
liberation from the iron trend of peacetime society toward mechanization, routine, and the suppression of the individual." Kennedy has argued that the older men produced a version of war, based on their own experiences, that glorified the possibilities for renewed masculine action in vigorous wartime activity. ${ }^{73}$

In the years following the European War, however, the authority of the older generation as spokesmen for nineteenth-century values was called into question. More and more in the 1920s, the conflict between the generations symbolized a tension between modernism and tradition. While social commentators emphasized the energy and excitement of the future, represented by the younger generation, they were also still sympathetic to traditional values, represented by the older generation. ${ }^{74}$ The concept of old age, particularly as contrasted to youth, continued to provide a way for popular writers to grapple with Americans' hopes for the future as well as memories of the past.

The represented conflict between generations of men and women illustrated the tension between older assumptions and the expectations of a new century. As one author explained, the whole question of the radical nature of the younger generation was based on the perspective of the older generation.

\begin{abstract}
The question is, are young people really what we think they are or are we crystallized and old-fashioned? ... There is no doubt that boys and girls have a freedom and a frankness which their elders never experienced. They pursue pleasure with an ardor that leaves the more recently emerged Puritans of an older generation astonished and aghast. But is it really any worse than the codified and conventionalized social life which was broken through clandestinely or suppressed to the point which has made it necessary for modern psychologists to establish clinics for the restoration of individuality ${ }^{75}$
\end{abstract}

The association between the generations and the different centuries resonated within popular literature and was used again and again in the following decades.

In the years after the European War, young people seemed in many ways to symbolize the energy and promise of the new century. As one author explained, only the youth of that day could get everyone through the contemporary crisis:

It was the splendid folly of youth that fought the war. An exhausted world is leaning on its strength to-day, on its light-hearted, if light-handed, meeting of new and difficult conditions, on its courage, its indomitable energy, its amazing and incredible insouciance which will enable it to skate over a social and economic ice so thin that it would crack under the careful foot of age. ${ }^{76}$

While youth could become synonymous with energy, the exhaustion of age expressed the anxieties of the new century: "Most of the pessimism, the foreboding, the gloominess, in the world today is probably simply the fatigue of spiritual old age." ${ }^{.77}$ As the United States began its new role as a world power during this time period, many commentators expressed concern with the nation's relationship to the rest of the world in terms of trying to balance the impetuous energy of youth and the traditional but failing power of old age.

In a variety of ways, social commentators used the language of generational conflict to illustrate the rapid changes in American culture and society as well as convey their ambivalence about these changes. The conflict between the younger and older 
generations seemed to express many of Americans' dilemmas in the 1920s, from racial strife to the introduction of new technologies to the changing meaning of memories about the past. The ambivalence of many of these discussions about the older and younger generations illustrated Americans' continuing difficulties with reconciling nostalgia about the past with hope for the future.

\section{EPILOGUE}

By the 1930s, the represented contest between the younger and older generations had largely been resolved in favor of youth, particularly young men. While the threat of new women's freedoms had created stresses for many social commentators of the 1920 s, women in the following decades did not realize the social or cultural possibilities imagined for them during the 1920s. Although there is still some dispute among historians about the extent to which women lost ground in the decades following the passage of the Nineteenth Amendment, women certainly lost much of the social and political momentum of the women's rights movements of the late nineteenth and early twentieth centuries. In addition, while ideals of womanhood may have become more open and flexible, the new generation of women never had the same social or cultural power as the new generation of men. ${ }^{78}$

The distinction between old and young remained important for men into the 1930s, particularly as older men became more subject to mandatory retirement and the new scrutiny of emerging professions of old age psychology and geriatrics. ${ }^{79}$ As a number of historians of old age have pointed out, by the 1920s young men and their achievements seemed to dominate society. ${ }^{80}$ Masculinity was redefined in the first few decades of the century such that efficiency and adherence to a business ideal seemed to be appropriately masculine and exemplified by young men. In contrast, reminiscences, slow pace, and inability to adapt to change were associated with older men and seemed less connected to masculinity. ${ }^{81}$

The 1920s public discussion about the crisis of youth was a turning point in the cultural relationship between generations of middle-class old and young men and women. Age became another way in which Americans could be organized, and gender was an important component to new understandings about age. The conflict between young and old raised questions about traditional male authority based on age. In addition, twentieth-century opportunities for women outside the home created new cultural relationships between men and women. But while the older binary distinction between men and women was reasserted in the decades after the 1920s, the most lasting consequence of the contest between the generations was the gradual marginalization of older men from cultural power.

\section{NOTES}

1. I am using Martin S. Pernick's idea of mass culture, which he defines as "any production made for a mass audience whether or not it was demonstrably 'popular' in origin." Pernick, The Black Stork: Eugenics and the Death of 'Defective'Babies in American Medicine and Motion Pictures since 1915 (New York: Oxford University Press, 1996), 14. See also Robert Sklar, Movie-Made America: A Cultural History of American Movies (New York: Vintage, 1994), 67-157; Lizbeth Cohen, "The Class Experience of Mass Consumption: Workers as Consumers in Interwar America," and Joan Shelley Rubin, "Between Culture and Consumption: The Medi- 
ation of the Middlebrow," in The Power of Culture: Critical Essays in American History, ed. Richard Wightman Fox and T. J. Jackson Lears (Chicago: University of Chicago Press, 1993), 135-60, 163-91. On the changes in advertising and consumer culture in this time period, see Roland Marchand, Advertising the American Dream: Making Way for Modernity, 1920-1940 (Berkeley: University of California Press, 1985); Jackson Lears, Fables of Abundance: A Cultural History of Advertising in America (New York: Basic Books, 1994).

2. On the political orientation and readership of these periodicals, see Edward E. Chielens, ed., American Literary Magazines: The Twentieth Century (New York: Greenwood, 1992). For an account of young working-class women in New York and their relationship to their families, see Kathy Peiss, Cheap Amusements: Working Women and Leisure in Turn-of-the-Century New York (Philadelphia: Temple University Press, 1986), 3-10, 67-72.

3. Lynn Hunt, "Introduction: History, Culture, and Text," in The New Cultural History, ed. Lynn Hunt (Berkeley: University of California Press, 1989), 1-22, quotation from p. 17. See also JoAnne Brown, "Professional Language: Words That Succeed," Radical History Review 34 (1986): 33-51.

4. Paul Boyer, Urban Masses and Moral Order in America, 1820-1920 (Cambridge, MA: Harvard University Press, 1978), 30-33.

5. Annie Kriegel, "Generational Conflict: The History of an Idea," Daedalus 107 (1978): 23-38.

6. For general histories of this time period, see Michael E. Parrish, Anxious Decades: America in Prosperity and Depression, 1920-1941 (New York: Norton, 1992); William E. Leuchtenberg, The Perils of Prosperity, 1914-1932 (Chicago: University of Chicago Press, 1958); Paul A. Carter, The Twenties in America (Arlington Heights, IL: AHM, 1975).

7. For changing social conditions for women in the late nineteenth and early twentieth centuries in the United States, see Sara M. Evans, Born for Liberty: A History of Women in America (New York: Free Press, 1989). For changing images of femininity during the twentieth century, see Sheila M. Rothman, Woman's Proper Place: A History of Changing Ideals and Practices, 1870 to the Present (New York: Basic Books, 1978), 97-174; Beth Haiken, "Plastic Surgery and American Beauty at 1921," Bulletin of the History of Medicine 68 (1994): 429-53. For changes in men's work culture and definitions of masculinity, see Michael Kimmel, Manhood in America: A Cultural History (New York: Free Press, 1996); Peter Filene, "Between a Rock and a Soft Place: A Century of American Manhood," South Atlantic Quarterly 84 (1985): 339-55; Clare Virginia Eby, "Babbitt as Veblenian Critique of Manliness," American Studies 34 (1993): 5-23; Eric J. Leed, No Man's Land: Combat and Identity in World War I (New York: Cambridge University Press, 1979).

8. Henry F. May, The End of American Innocence: A Study of the First Years of Our Own Time, 1912-1917 (New York: Knopf, 1959); James R. McGovern, "The American Woman's Pre-World War I Freedom in Manners and Morals," Journal of American History 55 (1968): 315-33.

9. Paula S. Fass, The Damned and the Beautiful: American Youth in the 1920s (New York: Oxford University Press, 1979), 6-7. For a critique of the ways in which popular literature of the 1920s did not represent many of the problems, conflicts, and experiences of that time period, see Dorothy M. Brown, American Women in the 1920s: Setting a Course (Boston: Twayne, 1987); Estelle Freeman, "The New Woman: Changing Views of Women in the 1920s," in Decades of Discontent: The Women's Movement, 1920-1940, ed. Lois Scharf and Joan M. Jensen (Westport, CT: Greenwood, 1983), 21-42.

10. Howard P. Chudacoff, How Old Are You? Age Consciousness in American Culture (Princeton, NJ: Princeton University Press, 1989), 29-48, 65-91.

11. This was originally part of my doctoral dissertation, in which I argued that old age as a cultural category did not develop its present form until the 1930s and 1940s. The conflict between the generations provided a framework for the emergence of this category (in the context of the economic crisis of the Great Depression and the growth of interest in old age by profes- 
sions such as psychology and medicine). Laura Davidow Hirshbein, "The Transformation of Old Age: Expertise, Gender, and National Identity, 1900-1950" (Ph.D. diss., Johns Hopkins University, 2000).

12. William Graebner has argued that the Social Security Act was more intended to provide jobs for younger men (by easing older men out of the job market) than it was to provide economic relief to older men. Graebner, A History of Retirement: The Meaning and Function of an American Institution, 1885-1978 (New Haven, CT: Yale University Press, 1980), 181-214.

13. See, for example, Alice Kessler-Harris's description of the gender assumptions of the framers and revisers of Social Security. Kessler-Harris, "Designing Women and Old Fools: The Construction of the Social Security Amendments of 1939," in U.S. History as Women's History: New Feminist Essays, ed. Linda K. Kerber, Alice Kessler-Harris, and Kathryn Kish Sklar (Chapel Hill: University of North Carolina Press, 1995), 87-106.

14. "Is the Younger Generation in Peril?" Literary Digest 69 (May 14, 1921): 9-12, 58-73; "The Case against the Younger Generation," Literary Digest 73 (June 17, 1922): 38-42, 51-63. For more on the Literary Digest articles, see Fass, The Damned and the Beautiful, 37-38. See also George Coe, What Ails Our Youth? (New York: C. Scribner's Sons, 1924); F. Scott Fitzgerald, Flappers and Philosophers (New York: Charles Scribner's Sons, 1920); Margaret Emerson Bailey, "A Chronicle of Youth by Youth," Bookman 46-47 (June 1920): 471-72; Julia Collier Harris, "Dreiser's Long Expected Novel Depicts the Turmoil and the Tragedy of Youth," Columbus (Ohio) Enquirer Sun, January 3, 1926, 445-47; Dorothy Parker, "Professional Youth," Saturday Evening Post 195 (April 28, 1923): 14, 156-57; “The 'Soviet of Youth' Again," Literary Digest 67 (October 16, 1920): 33.

The popular literature on juvenile delinquents was similar in many ways to the literature I describe in this article, but it generally dealt with a younger group of people (who were law breaking rather than tradition breaking) than those implicated in the crisis of youth. For a discussion of juvenile delinquency, see Anthony M. Platt, The Child Savers: The Invention of Delinquency (Chicago: University of Chicago Press, 1969).

15. "The Runaway Boy and Girl Problem," Literary Digest 81 (May 10, 1924): 31-32, quotation from p. 32. See also Laura Spencer Porter, “'Hello, Pop!'” Outlook 129 (November 9, 1921): 391-93; Vivian T. Pomeroy, "A Contemporary Challenge," Atlantic Monthly 136 (December 1925): 787-90; "Youth and Age," Forum 73 (May 1925): 750-53; G. S. Street, "Young and Old," Nineteenth Century and After 87 (June 1920): 1132-38; Clayton Hamilton, "Youth and Age in the Drama," Bookman 44 (December 1916): 396-400; Louise Creighton, "New Wine in Old Bottles," Contemporary Review 115 (April 1919): 431-46; W. T. Fitch, "Youth," Overland Monthly 87 (January 1929): 18; James Bissett Pratt, "Religion and the Younger Generation," Yale Review 12 (April 1923): 594-613; Anna Steese Richardson, "A Grandmother Speaks Her Mind," Pictorial Review 29 (March 1928): 2, 87-90; M. B. Stewart, "Youngsters vs. Oldsters," Scribner's Magazine 78 (August 1925): 125-27; "In Favor of the Young Folks," Literary Digest 73 (June 24, 1922): 34-38, 50-52; "The Sunny Side of Being One Hundred," Literary Digest 74 (July 29, 1922): 38-42; "The Failure of the Older Generation," Literary Digest 83 (December 13, 1924): 32-33; "Age and Crabbed Youth," Atlantic Monthly 145 (June 1930): 855-56. One commentator complained that too much of the popular press coverage of the older generation was from the perspective of the younger. See Laura E. Ridding, "Old Age," Contemporary Review 135 (June 1929): 735-40.

16. As an idea of how widespread and recognizable these representations were, the well-known actor Lionel Barrymore was interviewed to explain how he, as a man of 40, could so easily portray old men on the screen. Barrymore argued that he used characteristics of old men that his audiences would recognize. See Mary B. Mullett, "Lionel Barrymore Tells How People Show Their Age," American Magazine 93 (February 1922): 36-39, 84-86.

17. See, for example, Winifred Kirkland, "Grundyism," Outlook 127 (March 30, 1921): 509-10; "Runaway Boy and Girl Problem," 31-32; Porter, "Hello, Pop!'” 391-92; Pomeroy, "Contemporary Challenge," 787-90; Richard le Gallienne, "The Art of Not Growing Old," 
Harper's Monthly 142 (April 1921): 655-60; Brander Matthews, "Confessions of a Septuagenarian Contributor," Unpartizan Review 14 (July 1920): 97-108; Max McConn, "On Losing One's Disillusions," Nation 114 (April 5, 1922): 395.

18. Fass, The Damned and the Beautiful, 6-7.

19. "Our Disappointing Youngsters," Literary Digest 71 (December 17, 1921): 26.

20. Mr. Grundy, "Polite Society," Atlantic Monthly 125 (May 1920): 606-12, quotation from p. 609. The Mrs. Grundy character originally appeared in Thomas Morton's Speed the Plough (1797). Margaret Drabble, ed., The Oxford Companion to English Literature, 5th ed. (New York: Oxford University Press, 1985), 421, 673.

21. See also Booth Tarkington, "The Golden Age," American Magazine 101 (June 1926): 13-15, 110-4; Irvin S. Cobb, "The Generation That's Next," Saturday Evening Post 194 (September 17, 1921): 6-7, 62-65; Samuel Crowther, "When Is a Man Old? An Interview with Henry Ford," Ladies'Home Journal 46 (July 1929): 25, 132-33; A. B. Farguhar, "Life Gets to Be More Fun Every Day," Collier's 71 (February 17, 1923): 7-8.

22. Katharine Fullerton Gerould, "Reflections of a Grundy Cousin," Atlantic Monthly 126 (August 1920): 157-63, quotation from p. 162. See also Francis G. Peabody, "On Keeping Young," Atlantic Monthly 145 (June 1930): 820-24.

23. For a brief biographical sketch on Gerould, see "Katharine Fullerton Gerould," The Oxford Companion to American Literature, ed. James D. Hard with Phillip W. Leininger, 6th ed. (New York: Oxford University Press, 1995), 242. Gerould seemed to belong to an older tradition of women writers who exhorted their readers on religious themes. For a discussion of this tradition, see Ann Douglas, The Feminization of American Culture (New York: Knopf, 1977).

24. On American young men and the war, see David M. Kennedy, Over Here: The First World War and American Society (New York: Oxford University Press, 1980), 191-230.

25. John F. Carter Jr., " 'These Wild Young People' by One of Them," Atlantic Monthly 126 (September 1920): 301-34, quotation from p. 303.

26. A Last Year's Debutante, "Good-Bye, Dear Mr. Grundy," Atlantic Monthly 126 (November 1920): 642-46, quotation from pp. 643-44. (The Atlantic Monthly editors noted that they were protecting the identity of this young woman by publishing her article under a pseudonym.) See also "That Old Assignment," Unpartizan Review 14 (October 1920): 425-29.

27. For women's homosocial organizations, see, for example, Carroll Smith-Rosenberg, "The Female World of Love and Ritual: Relations between Women in Nineteenth-Century America," in Disorderly Conduct: Visions of Gender in Victorian America (New York: Oxford University Press, 1985), 53-76; Nancy Cott, Bonds of Womanhood: 'Women's Sphere' in New England, 1780-1835 (New York: Cambridge University Press, 1977). For men's homosocial organizations, see, for example, Mark C. Carnes, "Middle-Class Men and the Solace of Fraternal Ritual," in Meanings for Manhood: Constructions of Masculinity in Victorian America, ed. Mark C. Carnes and Clyde Griffen (Chicago: University of Chicago Press, 1990), 37-52; Mark C. Carnes, Secret Ritual and Manhood in Victorian America (New Haven: Yale University Press, 1989).

28. See, for example, Mary P. Ryan, Cradle of the Middle Class: The Family in Oneida County, New York, 1790-1865 (New York: Cambridge University Press, 1981); Linda Kerber, "Separate Spheres, Female Worlds, Women's Place: The Rhetoric of Women's History," Journal of American History 75 (1988): 9-39.

Some historians have argued that women made strides toward equal rights in the nineteenth century because of an ideology that posited some feminine qualities as important to society at large. For example, Regina Morantz-Sanchez has pointed out that women who succeeded in traditionally male professions such as medicine did so by articulating new definitions of professionalism appropriate to nineteenth-century definitions of femininity. Regina Markell MorantzSanchez, Sympathy and Science: Women Physicians and American Medicine (New York: Oxford University Press, 1985). 
29. For a suggestion of how middle-class men increasingly identified themselves with their families in the twentieth century, see Margaret Marsh, "Suburban Men and Masculine Domesticity, 1870-1915," in Carnes and Griffen, Meanings for Manhood, 111-27. Paula Baker has argued that gender became less important in American politics in the twentieth century. Paula Baker, The Moral Frameworks of Public Life: Gender, Politics and the State in Rural New York, 1870-1930 (New York: Oxford University Press, 1991).

30. Ann Douglas, Terrible Honesty: Mongrel Manhattan in the 1920s (New York: Farrar, Straus and Giroux, 1995), 3-28. Although social commentators in the early twentieth century frequently denigrated the power of past generations of women, women's organizations in the twentieth century continued to work for what Linda Gordon has described as maternalist goals. On women's organizations and activism in the late nineteenth and early twentieth centuries, see Linda Gordon, "Putting Children First: Women, Maternalism, and Welfare in the Early Twentieth Century," in Kerber, Kessler-Harris, and Kish Sklar, U.S. History as Women's History, 63-86; Nancy F. Cott, The Grounding of Modern Feminism (New Haven: Yale University Press, 1987); Ruth Bordin, Women and Temperance: The Quest for Power and Liberty, 1873-1900 (Philadelphia: Temple University Press, 1981); Theda Skocpol, Protecting Soldiers and Mothers: The Political Origins of Social Policy in the United States (Cambridge, MA: Harvard University Press, 1992).

31. Lois Banner has argued that older women in the first several decades of the twentieth century were represented in two dramatically different ways: they were either portrayed as full of energy, since their years of reproduction were through, or as sexually rapacious beings who preyed on younger men. Lois W. Banner, In Full Flower: Aging Women, Power, and Sexuality (New York: Vintage, 1992), 273-310. For a contemporary review of representations of older women, see Mary Lamberton Becker, "The Reader's Guide," Saturday Review of Literature 2 (July 3, 1926): 909; Catt, "The Years I Like Best".

32. Lillian Edgerton, "Is Good Behavior on a Vacation, Too?" Delineator 97 (July 1920): 25. See also "Etiquette or Courtesy?" Outlook 146 (June 15, 1927): 232; Helen Bullit Lowry, "Meeting the Right Young People," Delineator 99 (October 1921): 2; Gerould, "Reflections of a Grundy Cousin"; Alexander Black, "Is the Young Person Coming Back?" Harper's Magazine 149 (August 1924): 337-46.

33. Peter G. Filene, Him/Her/Self: Sex Roles in Modern America, 2d ed. (Baltimore: Johns Hopkins University Press, 1986), 122-35. Rosalind Rosenberg has also described some of the differences between generations of women in her illustrations of the work of the new women social scientists in Chicago in the early part of the twentieth century. See Rosenberg, Beyond Separate Spheres: Intellectual Roots of Modern Feminism (New Haven: Yale University Press, 1992).

34. Charlotte Perkins Gilman, "Vanguard, Rear-Guard, and Mud-Guard," Century 104 (July 1922): 348-53, quotation from p. 349. See also Gerould, "Reflections of a Grundy Cousin"; Fanny Heaslip Lea, "I'd Be Thirty Forever!" Good Housekeeping 77 (August 1923): 22-23, 104-6.

35. Not all women from the older generation were repressed, however. As one commentator pointed out, "Nowadays one is uneasily conscious that Grandmamma has fallen on evil times. Her chimney corner is comforted by an electric stove; the lace cap is out of fashion. ... So Grandmamma, in self-defense, has permanently waved her gray hair and shortened her skirts, and wears a sports' coat and plays golf. Everyone is young nowadays, and youngest of all is Grandmamma, who drives her own car and smokes a special brand of cigarettes and-dances." Clemence Dane, "When They Are Grandmothers," Forum 71 (May 1924): 647-50, quotation from p. 649. See also Ethel Lloyd Patterson, "Why Grow Old? Here's How I Took Ten Years off My Age," Ladies' Home Journal 39 (July 1922): 7, 46.

36. Annie G. Porritt, " 'When I Was Young-' A New Version of the Old Story about the Girls of Then and Now," Independent 105 (June 25, 1921): 660-61, 677-78, quotation from 
p. 677. See also "To-Day's Morals and Manners-The Side of 'the Girls,'” Literary Digest 70 (July 9, 1921): 34-42; Harriet Bronkhurst, "The Girl Whose Mother Is 'Old,' "Ladies' Home Journal 36 (June 1919): 132; Pomeroy, "Contemporary Challenge"; Reese Carmichael, "Those Dreadful Young Persons: A Popular Myth of the Present Day," Ladies' Home Journal 38 (May 1921): 18, 56; Edith M. Thomas, "The Case of 'My Daughter," Harper's Magazine 148 (December 1923): 127; Richardson, "A Grandmother Speaks Her Mind."

As Christina Simmons has pointed out, early-twentieth-century representations of the sexuality of the previous era emphasized the extreme repression of the Victorians, a version of the past that was largely myth. This myth could be used to come to terms with new freedoms for women, but it could also be used to realign male power: "The myth of Victorian repression rehabilitated male sexuality and cast women as villains if they refused to respond to, nurture, or support it. And by identifying women with Victorianism and men with a progressive and realistic understanding of sex, it confirmed men's sexual dominance as normative in modern marriage." Simmons, "Modern Sexuality and the Myth of Victorian Repression," in Gender and American History Since 1890, ed. Barbara Melosh (New York: Routledge, 1993), 17-42.

37. Carter, "'These Wild Young People,'” 303. See also "The Sons Better Than Their Fathers," Literary Digest 81 (June 14, 1924): 34; Helena Huntington Smith, "We Look at the Older Generation," Outlook 150 (November 14, 1928): 1166-67, 1181; Edwina Stanton Babcock, "The Winged Baby: An Allegory of the Younger Generation," Century 105 (January 1923): 356-65; Cornelia James Cannon, "The Crabbing of Youth by Age," Atlantic Monthly 131 (June 1923): 787-96; "Is the Younger Generation in Peril?" 9-12, 58-73.

38. Leslie Fishbein, "Dancing Mothers (1926): Flappers, Mothers, Freud, and Freedom," Women's Studies 12 (1986): 241-50, quotation from p. 246. See also Nathan G. Hale Jr., The Rise and Crisis of Psychoanalysis in the United States: Freud and the Americans, 1917-1985 (New York: Oxford University Press, 1995), 57-73; John C. Burnham, "The Influence of Psychoanalysis upon American Culture," in Paths into American Culture: Psychology, Medicine, and Morals (Philadelphia: Temple University Press, 1988), 96-110; Douglas, Terrible Honesty, 122-29.

39. Watson Davis, "Youth's Revolt as Science Sees It," Current History 25 (October 1926): 97. See also Smith, "We Look at the Older Generation," 1166-67, 1181.

40. "Release of Youth," 674. See also Cobb, "The Generation That's Next," 6-7, 62-65.

41. See, for example, Paul Popenoe, "Back to Methuselah," Scientific Monthly 25 (December 1927): 535-39. On disputes over birth control, along with fears about race suicide, see Linda Gordon, Woman's Body, Woman's Right: A Social History of Birth Control in America (New York: Penguin, 1976); Rothman, Woman's Proper Place, 188-200.

42. G. Stanley Hall, "Flapper Americana Novissima," Atlantic Monthly 129 (June 1922): 771-80, quotation from p. 780.

43. On anxieties about masculine young women, see Carroll Smith-Rosenberg, "The New Woman as Androgyne: Social Disorder and Gender Crisis, 1870-1936," in Disorderly Conduct, 245-96.

44. Gilbert Frankau, "Can the Modern Girl Love?" Forum 68 (November 1923): 917 (second ellipses in the original). See also R.S.V.P., "Girls," Atlantic Monthly 125 (April 1920): 490-95; "The Release of Youth," Nation 110 (May 22, 1920): 674; J. Madison Taylor, "The Man Young at Fifty," Medical Times 49 (1921): 39-41; "Is the Younger Generation in Peril?" 9-12, 58-73. 45. "To-Day's Morals and Manners," 36.

46. R.S.V.P., "Girls," 491. See also "Reproach of the Runaway Girl," Literary Digest 69 (June 11, 1921): 29-30; "Runaway Boy and Girl Problem," 31-32.

47. "Case against the Younger Generation," 60.

48. "Beauty and the Devil," Literary Digest 81 (May 31, 1924): 35. See also "Opelousas' Record-Aged Pedestrian, Lover, and Philosopher," Literary Digest 75 (October 21, 1922): 44-48. 
49. Alfred E. Stearns, "Give Youth Its Chance," Woman's Home Companion 49 (May 1922): 7. See also "Canine Destination of the Young Folks Doubted," Literary Digest 80 (February 9, 1924): 32-33.

50. "The Clean-Heartedness of Youth," Literary Digest 73 (April 15, 1922): 38.

51. "Is the Younger Generation in Peril?" 12.

52. A poem from the Stanford College paper, reprinted in the Literary Digest (73 [June 17, 1922]: 38), illustrates some of the animosity even young men could generate toward young women.

Who was this wild and winsome coot That made poor Adam pull the boot And taste of that forbidden fruit? A Flapper.

This Cleopatra maiden fair

For whom great Caesar tore his hair

Who was this vamp so debonair

A Flapper.

Who was this biddy called Salome

That robbed John Baptist of his dome,

The one that made mere man leave home?

A Flapper.

Who is it now that flashes by

With scanty clothes and dropping eye,

For whom some sap would gladly die?

A Flapper.

Who strokes the profs upon their nobs,

And on their shoulders gently sobs

While some swell mark from them she robs

A Flapper.

Who is it spends their hard-earned kale

Who makes this plant a woeful tale

Who is more deadly than the male?

A Flapper.

53. Mr. Grundy, "Polite Society," 609. See also Mather A. Abbott, "The New Generation," Nation 123 (8 December 1926): 588.

54. George Santayana, “America's Young Radicals," Forum 67 (May 1922): 372; "George Santayana," in Drabble, Oxford Companion, 865-66. See also Willard Thorp, "This Flapper Age," Forum 68 (August 1922): 639-43; By '90, "Ferguson—Rex," Atlantic Monthly 134 (September 1924): 355-60; A. Maude Royden, "The Destructive Younger Generation: Its Critical Open Mind Tears Down the Old Faith, but Builds Up Nothing," Ladies' Home Journal 41 (March 1924): 31, 174; S. K. Radcliffe, "The License of the Youngsters," Century 102 (July 1921): 390-96; Cobb, "The Generation That's Next," 6-7, 62-65; Ernest Martin Hopkins, "The Faith of the Fathers," Scribner's Magazine 83 (February 1928): 133-41; “The League of Youth," New Republic 31 (June 28, 1922): 123-24. One author argued that certain subjects required the maturity of an older mind to properly assimilate. See Merle Crowell, "Is Your Brain Power Increasing with Age?" American Magazine 95 (January 1923): 12-13, 100-103.

55. Allan Armstrong Hunter, "The Stirring of Youth," Forum 72 (December 1924): 787-93, quotation from p. 792. See also "The Young Persona non Grata," Independent 112 (24 May 1924): 286, 290.

56. "The Flapper as a Religious Force," Literary Digest 77 (May 19, 1923): 34. See also "Youth," Scribner's Magazine 67 (March 1920): 378-79; Thomas Beer, "A Little Exam: A Note on the Younger Generation," Scribner's Magazine 89 (January 1931): 78-80; Tarkington, "Golden Age"; Carrie Chapman Catt, "The Years I Like Best," Good Housekeeping 77 (October 
1923): 17, 181-84; William Johnston, "I Wish I Had-" Good Housekeeping 76 (May 1923): 27, 198-203; Edward S. Martin, "Long Life or Not?" Harper's Monthly 151 (June 1925): 122-25; Edward S. Martin, "Commencement, Longevity, the Great Fourth," Harper's Monthly 153 (September 1926): 521-22; Will Payne, "Chloroform at Sixty?" Saturday Evening Post 199 (April 2, 1927): 35, 110-4; William Lyon Phelps, "The Salt of Old Age," Delineator 117 (December 1930): 15, 62-65; Leslie B. Spencer, "Three Men with a Wonderful Record," American Magazine 91 (March 1921): 52; "Look to Your Laurels, Oh Age!" Current Opinion 73 (December 1922): 776.

57. Cyril Falls, "The Youth That Must Be Served," Nineteenth Century and After 92 (August 1922): 340-48, quotation from pp. 340-41. See also "Debating Barrie's View of Courage," Literary Digest 74 (August 5, 1922): 34-35; "Failure of the Older Generation," 32-33.

58. Hunter, "Stirring of Youth," 791. See also Stanley High, "Would We Do It Again," Collier's 73 (May 31, 1924): 7, 29; Ellen Wells Page, "A Flapper's Appeal to Parents," Outlook 132 (December 6, 1922): 607; Don Marquis, "Youth's Questionnaire: Submitted to the Older Generation by the Intelligent Flapper and Her Boy Friends," Outlook 149 (May 30, 1928): 177; "A Plea for the Defendants by One of the Younger Generation," Woman's Home Companion 48 (March 1921): 2; "Barrie's 'League of Youth," Literary Digest 73 (May 20, 1922): 32-33; "Case against the Younger Generation," 38-42, 51-63.

59. See, for example, James M. Beck, "America's Need of Youth," Saturday Evening Post 193 (May 14, 1921): 8, 74, 77.

60. "Depression," Outlook 133 (April 11, 1923): 648.

61. John Carter, "Old Men in Politics: As Seen in Recent Books," Outlook 154 (April 23, 1930): 669-70, quotation from p. 670. See also George B. Sims, "The Old Folks and the War," Living Age 298 (August 10, 1918): 358-60; R.S.V.P., "Boys," Atlantic Monthly 125 (March 1920): 339-51.

62. Street, "Young and Old," 1137. See also Archibald Weir, "Old Age: Redeemed and Unredeemed," Contemporary Review 124 (November 1923): 619-25.

63. Meredith Nicholson, "The Oldest Case on the Calendar," Harper's Magazine 144 (December 1921): 27-34, quotation from p. 34. See also Rollo Ogden, "Viewpoint of a Sexagenarian Contributor," Unpartizan Review 14 (July 1920): 90-96; Payne, "Chloroform at Sixty?"; Stewart, "Youngsters vs. Oldsters"; J. Madison Taylor, "The Enterprise of a Survival and Reestablishment after Three Score Years," Medical Times 49 (1921): 20-23; "On Keeping One's Figure," Scribner's Magazine 71 (March 1922): 377-78. To further the bonding between generations of men, older writers frequently blamed women. For example, one older man suggested that the only problems with young men stemmed from being led astray by their mothers' bad habits. William Lyon Phelps, "The American Home and the Younger Generation," World's Work 48 (October 1924): 638-42.

64. Psychologist G. Stanley Hall observed that, once he got beyond the age at which women found him attractive, he was much more interested in men's company. Anonymous [G. Stanley Hall], "Old Age," Atlantic Monthly 127 (January 1921): 23-31. See also "On Making a Very Common Discovery," Atlantic Monthly 126 (October 1920): 571-72.

65. Douglas, Terrible Honesty, 73-107. For discussions of race antagonisms during this time period, see Nell Irvin Painter, Standing at Armageddon: The United States, 1877-1919 (New York: Norton, 1987), 216-30; William M. Tuttle, Race Riot: Chicago in the Red Summer of 1919 (New York: Atheneum, 1970); Kathleen M. Blee, Women of the Klan: Racism and Gender in the 1920s (Berkeley: University of California Press, 1991). Chip Rhodes has described ways in which white writers used images of race to express their own agenda. See Chip Rhodes, "Writing Up the New Negro: The Construction of Consumer Desire in the Twenties," Journal of American Studies 28 (1994): 191-207.

66. "Elder, Not Better," Atlantic Monthly 130 (October 1922): 570-72, quotation from p. 571. See also Ernle, "The Revolt of Youth," Nineteenth Century and After 88 (December 1920): 925-34. One author appropriated a caricatured black dialect to describe the advantages of a 
woman's advancing age — that her appearance no longer mattered. See Dorothy Dix, "The Joy of Being Fifty," Good Housekeeping 77 (September 1923): 23, 158-59.

67. Stephanie Coontz has pointed out that Americans have typically become enamored with a vision of family unity that has been largely myth. Coontz, The Way We Never Were: American Families and the Nostalgia Trap (New York: Basic Books, 1992).

68. D. W. Griffith illustrated one relationship between a white family and race relations. In his 1914 film, The Birth of a Nation, Griffith portrayed post-Civil War white society as a family (which had been divided by the war) reunited to fight off the threat of blacks. See Michael Paul Rogin, " 'The Sword Became a Flashing Vision': D. W. Griffith's The Birth of a Nation," in Ronald Reagan, the Movie, and Other Episodes in Political Demonology (Berkeley: University of California Press, 1987), 190-235.

69. "Courting Danger in the Automobile," Literary Digest 82 (July 5, 1924): 35. See also Abbott, "New Generation," 587-88; Florence Guy Woolston, "Girls—And Then Some," New Republic 30 (March 15, 1922): 77-80; George Ade, "To-Day's Amazing Crop of Eighteen-Year Old Roués and Nineteen-Year Old Vamps," American Magazine 193 (March 1922): 5-7, 146-47; Cannon, "Crabbing of Youth"; Richard King, "Watching the World Go By," Forum 70 (December 1923): 2252-55; Chase S. Osborn, "Then and Now," Outlook 148 (March 28, 1928): 498-99, 509; W. O. Saunders, “Tick-Tock!” American Magazine 107 (February 1929): 18-19, 86-94.

70. Lears also addressed the propensity of older histories of the Progressive Era to view the late nineteenth and early twentieth centuries as only characterized by progressive movement and ideals about the future. T. J. Jackson Lears, No Place of Grace: Antimodernism and the Transformation of American Culture, 1880-1920 (Chicago: University of Chicago, 1981). For some older accounts of this time period that illustrate Lears's point, see, for example, Samuel Haber, Efficiency and Uplift: Scientific Management in the Progressive Era, 1890-1920 (Chicago: University of Chicago Press, 1964); Samuel P. Hays, Conservation and the Gospel of Efficiency: The Progressive Conservation Movement, 1890-1920 (Cambridge, MA: Harvard University Press, 1959); Robert H. Wiebe, The Search for Order: 1877-1920 (New York: Hill and Wang, 1967).

71. Michael Kammen, The Mystic Cords of Memory: The Transformation of Tradition in American Culture (New York: Vintage, 1991), 93-296. See also John Bodnar, Remaking America: Public Memory, Commemoration, and Patriotism in the Twentieth Century (Princeton, NJ: Princeton University Press, 1992).

72. May, End of American Innocence, quotation from p. 6.

73. Kennedy, Over Here, 178-79, 228.

74. See, for example, Sarah Comstock, "The Peppermint Years," Harper's Monthly 159 (July 1929): 180-88; Crowther, "When Is a Man Old?"; Ernle, "Revolt of Youth"; A. B. Farquhar, "Life Gets to Be More Fun Every Day," Collier's 71 (February 17, 1923): 7-8; Fitch, "Youth"; W. L. George, “As We Get Older," Harper's Magazine 141 (September 1920): 522-29; Corra Harris, "Fortune Telling for Old People," Ladies' Home Journal 43 (May 1926): 33, 198; Hopkins, "Faith of the Fathers."

75. Woolston, "Girls - And Then Some," 79. See also Edward Marshall, "Youth of To-Day and To-Morrow: An Authorized Interview with Thomas A. Edison," Forum 77 (January 1927): 41-53; "Our Disappointing Youngsters," 26; Black, "Is the Young Person Coming Back?"; William Lyon Phelps, "Youth," Delineator 117 (August 1930): 12, 38-40.

76. Eleanor Chalmers, "How Old Are You?" Delineator 99 (January 1922): 23. See also R.S.V.P., "Boys"; Clemence Dane, "What Is Youth," Forum 78 (September 1927): 343-45; Ogden, "Viewpoint of a Sexagenarian Contributor."

77. "Depression". See also Corra Harris, "The Prosody of Old Age," Saturday Evening Post 198 (May 8, 1926): 35, 149; Corra Harris, "The Borrowed Timers," Ladies' Home Journal 43 (September 1926): 35, 209. 
78. For discussions about women's inability to maintain momentum after suffrage, see Nancy F. Cott, Grounding of Modern Feminism, 145-74; Lois Scharf and Joan M. Jensen, eds., Decades of Discontent: The Women's Movement, 1920-1940 (Westport, CT: Greenwood, 1983). In addition to the failure of political aims, Joan Jacobs Brumberg has noted the increasing amount of time that young women devoted to body image and weight loss beginning by the 1920s. Brumberg, The Body Project: An Intimate History of American Girls (New York: Random House, 1997), 97-107.

79. For more on the emergence of retirement after the Social Security Act of 1935, see Graebner, History of Retirement; Brian Gratton, Urban Elders: Family, Work and Welfare among Boston's Aged, 1890-1950 (Philadelphia: Temple University Press, 1985). Psychologists began to inquire into intelligence in old age in the 1930s, and the medical specialty of geriatrics (medical care of patients in the later years of life) was formally recognized with the 1942 founding of the American Geriatrics Society. For more on the 1930s and 1940s growth of gerontology and geriatrics, see W. Andrew Achenbaum, Crossing Frontiers: Gerontology Emerges as a Science (New York: Cambridge University Press, 1995).

80. See David Hackett Fischer, Growing Old in America (New York: Oxford University Press, 1978), 113-56; W. Andrew Achenbaum, Old Age in the New Land: The American Experience Since 1790 (Baltimore: Johns Hopkins University Press, 1978), 39-54.

81. Betty Friedan has observed that current ideas about masculinity seem to be based on the abilities and attitudes of young men. See Friedan, The Fountain of Age (New York: Simon \& Schuster, 1993), 165-87. 